\author{
Ярослава Василькевич, \\ кандидат психологічних наук, \\ дочент, доцент кафедри психологіі \\ ДВНЗ «Переяслав-Хмельницький \\ державний педагогічний \\ університет імені Григорія \\ Сковороди»
}

\author{
Yaroslava Vasylkevych, \\ PhD in Psychology, Associate \\ Professor, Associate Professor of the \\ Department of Psychology \\ SHEI «Pereiaslav-Khmelnytskyi \\ Hryhorii Skovoroda \\ State Pedagogical University»
}

\title{
ПРОБЛЕМА ЕФЕКТИВНОСТІ ТА ІНТЕРПРЕТАЦІЇ ГРАФІЧНИХ ПРОЕКТИВНИХ МЕТОДІВ СІМЕЙНОЇ ДІАГНОСТИКИ
}

У статті проаналізовано можливості застосування та проблеми ефективності проективних графічних тестів. Розглянуто основні принципи оцінки (інтерпретації) малюнка при проведенні психологічного обстеження, які необхідно враховувати практичному психологу. Описано графічні проективні методи сімейної діагностики, спрямовані на виявлення особливостей емоційних переживань дитини щуодо ї̈ міжособистісної взаємодї та суб'єктивної сімейної ситуації. Наведено основні критерії детальної оцінки особливостей внутрішньосімейних стосунків за неструктурованим проективним тестом малюнку сім' $i$ (відсутність на малюнку одного з членів сім'ї; відсутність на малюнку самого автора; простір аркуша, заповнений малюнком; розміщення фігур на аркуші; зображення неживих предметів; розмір зображеного персонажу або предмету; розмір та особливості зображення окремих частин тіла персонажів; зображення на малюнку персонажів, які офіційно не належать до сім' $\dddot{\imath ;}$ розміщення автора та інших персонажів на аркуші стосовно інших фігур; відстань між фігурами тощя). Подано систему кількісної очінки тесту Кінетичний малюнок сім '̈̈, де виділено n'ять симптомокомплексів: 1) сприятлива сімейна ситуація; 2) тривожність; 3) конфліктність у сім $\dddot{i}$; 4) почуття неповноцінності; 5) ворожість у сімейній ситуації. Виділено три групи запитань для бесіди після малювання: 1) провокативні запитання, які схиляють дитину до відкритого обговорення почуттів; 2) сочіометричні запитання для здійснення дитиною негативного і позитивного вибору; 3) запитання, спрямовані на вияснення смислу намальованої ситуації або певних деталей. Виділено модифікації тесту: використання кольорових олівців; малювання сім' $і$, яка зайнята якоюсь справою; використання тесту для дорослих і всієї сім' загалом; малювання сім'ї в скрутній ситуачії; сім'я у вигляді символів; сумісний малюнок сім'ї.

Ключові слова: графічні проективні методи, якісний аналіз, кількісна оцінка, формальний та змістовий аспекти, симптомокомплекси.

The article deals with opportunities and the problems of effectiveness of projective graphic tests usage. Basic principles of evaluation (interpretation) of the picture, which have to be considered by a practical psychologist during conducting a psychological examination are considered. Graphic projective methods of family diagnostics aimed at detection of the peculiarities of the emotional experiences of the child in relation to their interpersonal interaction and subjective family situation are described. The main criteria of detailed assessment of the characteristics of inter-family relationships by unstructured family drawing projective test are outlined (absence of a picture of a family member; absence of the author in the image; space of a sheet filled with drawing; placing figures on a sheet; images of inanimate objects; the size of the character or the subject depicted; the size and features of the image of the parts of the characters; images of non-family characters; placing the author and other characters on a sheet in relation to other figures; distance between figures etc.). The system of quantitative evaluation of the Kinetic test is presented. Five symptom complexes are highlighted: 1) favorable family situation; 2) anxiety; 3) family conflict; 4) feelings of inferiority; 5) hostility in the family situation. Three groups of questions for conversation after drawing are listed: 1) provocative 
questions that encourage the child to discuss feelings openly; 2) sociometric questions for the child to make negative and positive choices; 3) questions to clarify the meaning of the drawn situation or certain details. Test modifications are highlighted: usage of colored pencils; drawing a family that is busy with a business; use of the test for adults and the whole family; drawing a family in a difficult situation; family in the form of symbols; compatible family drawing.

Keywords: graphic projective methods, qualitative analysis, quantitative evaluation, formal and substantive aspects, symptom complexes.

Постановка проблеми. Проективні графічні тести $є$ досить перспективними у психологічній практиці. Проте при їх використанні, на відміну від стандартизованих і структурованих діагностичних методик, гостро постає питання про якість інтерпретації тестової інформації. Малювання дітей - складна синтетична діяльність, яка характеризується проявом різних сторін психічного розвитку; використанням досвіду, набутого в різних видах дитячої діяльності; засвоєнням різнорідних елементів соціального досвіду, людської культури. У малюванні виявляється особистість дитини, яка формується. Тому психологи через дитяче малювання шукають можливість проникнути у своєрідний внутрішній світ дитини. Методики, засновані на використанні малюнків дитини, займають чи не центральне місце в діяльності практичного психолога. Цей продукт діяльності дітей входить практично в усі напрями психологічної діагностики та корекції.

Проте певна простота інструментарію, процедури проведення та інтерпретації малюнкових тестів при незнанні, неврахуванні основних принципів оцінки та аналізу дитячого малюнка може призвести до значних помилок при проективній трактовці образотворчої продукції дітей. В аналізі дитячого малюнка необхідно враховувати закони його формування в онтогенезі, особливості графічних зображень i «нормативних» проекцій, характерні для малюнків дітей різного віку.

Аналіз останніх досліджень $\boldsymbol{i}$ публікацій. Одним із перших запропонував використовувати малюнок сім'ї з психодіагностичною метою В. Хьюлс [Hulse, 1951]. Удосконалення методики здійснювалося в напрямку зміни інструкції до завдання та розширення діапазону параметрів інтерпретації малюнка [Hulse, 1952; Corman, 1964]. Розроблено ряд модифікацій тесту 3 варіантами застосування та обробки результатів. В інструкції дитину просять або «намалювати сім'ю», або «намалювати свою сім'ю» [Hulse, 1952; DiLeo, 1973], або «намалювати всіх членів своєї сім'ї, які чимось зайняті» («Кінетичний малюнок сім'ї») [Burns \& Kaufman, 1970] тощо. Запропоновано варіанти, які передбачають тривалу бесіду після малювання за певними запитаннями та за змістом малюнка [Corman, 1964], або можуть проводитися як окремо 3 дитиною, так і з усіма членами сім'ї [Shearn, Russell, 1969], що дає можливість порівняти бачення сімейних стосунків батьком, матір'ю та дітьми. Малюнкові проективні методи сімейної діагностики отримали широке 


\section{Psychology}

розповсюдження в роботі практичних психологів завдяки роботам С. Кауфмана, Л. Кормана, В. Хьюлса, Дж. Ділео, Р. Бернса, Р. Беляускайте, А. Захарова, Г. Хоментаускаса, С. Романової, В. Лосєвої. Неструктуровані проективні методики дають людині можливість своєрідно відображати та інтерпретувати внутрішню і зовнішню реальність. Отриманий в результаті їхнього застосування продукт творчої діяльності розкриває індивідуальнотипологічні характеристики особистості: уявлення, стани, почуття, ставлення. «Малюнок сім’ї» призначений для виявлення особливостей емоційних проблем і ставлень у сім’ї.

Виклад основного матеріалу. Для уникнення помилок при використанні малюнкових проб у діяльності практичного психолога необхідне дотримання основних принципів оцінки (інтерпретації) дитячого малюнка при проведенні психологічного обстеження [Семаго, Семаго, 2005: c. 328]:

1. Врахування нормативних особливостей формування графічної діяльності та малюнка 3 віком і законів розвитку малюнка при його трактовці.

2. Оцінка малюнка не тільки з точки зору рівня розвитку, але й 3 точки зору специфічних ознак.

3. Аналіз малюнка як індикатора не тільки творчих здібностей, але й патологічних процесів (функціональних і органічних).

4. Використання єдиного формату паперу та однотипного малювального матеріалу, наприклад олівців середньої м’якості (M2) і т. д.

5. Створення малюнка дітьми дошкільного та молодшого шкільного віку в рамках обстеження повинне відбуватися в атмосфері ігрової та неоцінюваної діяльності.

6. Пріоритет для аналізу в індивідуальній діагностиці повинні мати, перш за все, малюнки, за виникненням яких була можливість спостерігати.

7. Врахування емоційних та інших проявів дитини в процесі самого малювання, а також таких особливостей, як словесний супровід, якою рукою малює та яким способом тримає олівець, змінювання положення аркуша паперу в процесі малювання, заміна (поломки) олівців і інше.

8. Включення до аналізу відомостей, які стосуються сформованості схеми та образу власного тіла, оскільки останні здійснюють безпосередній вплив і на характер зображення фігури людини, і на особливості графічної діяльності загалом. сприймання дитини.

9. Попередній аналіз і врахування особливостей зорового

10. Використання малюнка ніколи не може бути єдиним відправним пунктом проективної інтерпретації. Проективні тенденції слід перевіряти за допомогою інших досліджень, співставлення з результатами подальших випробувань, у розмові з батьками і т. п. 
11. Значно більша кількість помилок у психологічній діагностиці спричиняється перебільшенням проективної інтерпретації малюнка, аніж недостатністю проективної інтерпретації.

До суб'єктивних і невиправданих психодіагностичних заключень призводить також відсутність єдиної та обгрунтованої системи інтерпретації показників графічних методик. Кожен показник дитячих малюнків трактується в основному ізольовано, без зв'язку з іншими. Проте для достатньо обгрунтованого висновку треба опиратися на систему показників, доповнюючи тї інформацією 3 інших джерел (бесід, спостережень).

Г. Хоментаускас [Хоментаускас, 1985] провів дослідження, що дозволяе обгрунтувати методику малювання сім'ї як процедуру, яка відображатиме в першу чергу переживання і сприйняття дитиною свого місця в сім'ї, а також ставлення дитини до сім'ї загалом і до окремих іiі членів.

Негативні переживання дитини (7-8 років), пов'язані 3 сім'єю, незадоволеність сімейною ситуацією відображаються вже у самому ставленні до завдання: спостерігаються захисні реакції, що набувають форму трансформації завдання (малювання тільки не пов'язаних з родиною людей або взагалі відмова від зображення людей), відкладання виконання релевантного завдання у часі (початок малювання з різних об'єктів). Таким дітям властиве спотворення складу сім'ї, зменшення складу сім'ї, включення до складу сім'ї людей, які з нею безпосередньо не пов'язані. Ставлення дітей до сім'ї та окремих іiі членів виражається в характері розташування членів сім'ї на малюнку, в їхній згуртованості, в тому, чи малює дитина себе разом з іншими членами сім'ї чи окремо. Виявлено, що 3 почуттям незадоволеності, знехтуванням пов'язана поява в малюнку зображення хмар (дощу) і сонця, розташування членів сім'ї на лінії основи. Ці характеристики, напевно, мають символічне значення і відображають відповідно почуття пригніченості, потребу в любові, потребу в безпеці.

За допомогою факторного аналізу виділено два виміри, що в психологічному сенсі відображають:

1. Почуття дитини щодо сім'ї, сімейної ситуації, свого місця в ній («відчуття знедоленості, почуття приналежності»). Цей вимір описується таким протиставленням характеристик малюнка: зменшення складу сім'ї, хмари, сонце, лінія основи, початок малювання з об'єкта - згуртованість сім'ї, «Я» поруч з іншими.

2. Спосіб «переробки» почуття знехтування («символічне вигнання сім'ї - символічне вигнання себе»). Цей вимір диференціює полюс фактора «почуття знехтування» i описується протиставленням наступних характеристик: присутність не пов'язаних з родиною людей, «Я» єдина фігура - відсутність «Я». 


\section{Psychology}

Г. Хоментаускас [Chomentauskas, 1983] виділив і способи, за допомогою яких діти (7-8 років) виражають своє ставлення до конкретних намальованих людей.

Емоційне ставлення дитини, представлене факторами «силаслабкість», «любимість-нелюбимість», має чітку графічну презентацію за допомогою семантично насичених засобів виразної мови малюнка.

Факторний аналіз малюнків «сильної-слабкої» людини виділив тип малювання, в якому атрибуція «сили» передається головним чином за допомогою зміни співвідношення висоти, ширини i площі фігури. Кількісний аналіз також виявив, що «сила» передається за допомогою малювання піднятих рук, зображенням об'єктів у руках.

Факторний аналіз «улюбленої-нелюбимої» людини виділив два типи графічної презентації. Для обох характерна передача переваги «улюбленого» над «нелюбимим» через кількість деталей тіла, квітів, декорування.

Таким чином, факторний аналіз дозволяє виокремити основні параметри емоційного ставлення дитини до членів сім'ї, що відповідають осям «симпатія» і «повага».

Метою тесту є діагностика внутрішньосімейних стосунків. Тест допомагає виявити ставлення дитини до членів своєї сім'ї, те, як вона сприймає кожного 3 них і свою роль у сім'ї, а також ті взаємини, які викликають у дитини тривожні й конфліктні почуття.

Ситуація в сім'ї, яку батьки оцінюють позитивно, може бути сприйнята дитиною абсолютно протилежно. Дізнавшись, яким вона бачить навколишній світ, сім'ю, батьків, себе, можна зрозуміти причини виникнення багатьох проблем дитини та ефективно допомогти ій при їхньому вирішенні.

Г. Хоментаускас [Хоментаускас, 2004] пропонує найбільш детальну діагностичну процедуру проведення методики «Малюнок сім’ї» Матеріали, необхідні для проведення дослідження: стандартний чистий аркуш паперу формату A4 (21х29 см), простий олівець 2M, ластик. Додатково можна запропонувати шість кольорових олівців (чорний, червоний, синій, зелений, жовтий, коричневий).

У протоколі фіксується час виконання завдання, всі запитання i висловлювання досліджуваного, стирання, виправлення та інше.

При виконанні завдання слід відзначати у протоколі:

а) послідовність малювання деталей;

б) паузи більше 15 секунд;

в) витирання деталей;

г) спонтанні коментарі дитини;

д) емоційні реакції та їхній зв'язок із зображуваним змістом.

При проведенні методики в жодному разі не можна пояснювати, що позначає слово «сім'я», тому що цим спотворюється сама суть дослідження. Якщо дитина запитує, що йому малювати, психолог повинен 
повторити інструкцію. Час виконання завдання не обмежується (у більшості випадків воно триває не більше 35 хвилин).

Із бесіди 3 дитиною, яка проводиться після самого процесу малювання, слід дізнатися:

a) чия сім'я зображена на малюнку - сім'я дитини, його друга чи вигаданого героя;

б) де знаходяться зображені персонажі та чим зайняті в даний момент;

в) якщо брати кожен персонаж окремо, то якої він статі та яка його роль у сім'ї? що вони роблять? хто це придумав?;

г) хто з них найприємніший і чому, хто найщасливіший і чому;

д) хто найсумніший і чому;

є) кому надає перевагу сама дитина з усіх персонажів і чому;

ж) якби всі зібралися на прогулянку на автомобілі, але місця на всіх не вистачило, то хто б з них залишився вдома;

3) якщо хтось із дітей поводиться погано, як він буде покараний.

Питання «г» $\mathrm{i}$ «д» провокують дитину на відкрите обговорення почуттів, що схильна робити не кожна дитина. Тому, якщо дитина не відповідає на них або відповідає формально, не слід наполягати на експліцитній відповіді. При опитуванні психолог повинен намагатися з'ясувати сенс намальованого дитиною: почуття до окремих членів сім'ї; чому дитина не намалювала кого-небудь з членів сім'ї (якщо так сталося); що означають для дитини певні деталі малюнка (птахи, звірята і т. д.). При цьому по можливості слід уникати прямих запитань і наполягати на відповіді, оскільки це може індукувати тривогу, захисні реакції. Часто продуктивними виявляються проективні запитання (наприклад: «Якщо замість пташки була би намальована людина, то хто б це був?», «Хто б виграв у змаганнях між братом і тобою?», «Кого мама покличе йти 3 собою?» тощо).

Після опитування дитині пропонують обговорити 6 ситуацій: три 3 них мають виявити негативні почуття до членів сім'ї, три - позитивні:

1. Уяви собі, що в тебе є два квитки в цирк. Кого б ти покликав 3 собою?

2. Уяви, що вся твоя сім'я йде в гості, але один 3 вас захворів і повинен залишитися вдома. Хто він?

3. Ти будуєш 3 конструктора будинок (вирізаєш паперове плаття для ляльки) і в тебе погано виходить. Кого ти покличеш на допомогу?

4. Ти маєш квитків (на один менше, ніж членів сім'ї) на цікавий фільм. Хто залишиться вдома?

5. Уяви собі, що ти потрапив на безлюдний острів. 3 ким би ти хотів там жити?

6. Ти отримав у подарунок цікаве лото. Вся родина сіла грати, але вас однією людиною більше, ніж треба. Хто не буде грати?

Для інтерпретації також треба знати: 


\section{Psychology}

а) вік досліджуваної дитини;

б) склад iii сім'ї, вік братів і сестер. Бажано мати відомості про поведінку дитини в сім'ї, дитячому садку або школі.

Л. Корман [Corman, 1964] для бесіди після малювання пропонує серію запитань, які можна розділити на три групи:

1. Провокативні запитання, які схиляють дитину до відкритого обговорення почуттів. Наприклад: «Хто в сім’ї найбільш неприємний? Хто найсумніший? Хто в сім'ї найбільш нещасний?»

2. Соціометричні запитання, відповідаючи на які, дитина повинна зробити негативний і позитивний вибір. Наприклад: «Коли вони завершать цю справу та підуть на прогулянку, хто залишиться вдома? Якщо мама не встигатиме приготувати обід, хто буде або не буде допомагати їй? Батько задумав поїздку автомобілем, але в ньому не вистачає місця для всіх. Хто залишиться вдома?»

3. Запитання, спрямовані на вияснення того, який смисл для дитини мають намальована ситуація або певні деталі. Наприклад: «Котик на малюнку кого більше любить? А кого боїться?»

У діяльності шкільних психологів буде корисним досвід модифікації графічної проективної методики для психологічного діагностування дитини, здійсненої Р. Беляускайте [Беляускайте, 1987: c. 67-80]. Вона запропонувала стандартну процедуру іï індивідуального застосування та системний підхід до аналізу результатів. Для цього загальноприйняті показники малюнків було згруповано в ряд симптомокомплексів, кожен 3 яких характеризував окрему особистісну рису або особливості взаємостосунків 3 оточуючими. Для кожного показника малюнка передбачена оцінка в балах, що залежить від його вираженості та значущості для тієї характеристики, до якої цей показник відноситься.

Запропонований варіант тесту «Кінетичний малюнок сім’ї» (КМС) зручний для практичного використання, інформативний, при повторному використанні може демонструвати динаміку психічного стану. Тест КМС надає багату інформацію про суб'єктивну сімейну ситуацію досліджуваної дитини. Він допомагає виявити ставлення дитини до членів своєї родини та сімейні стосунки, які викликають тривогу або конфлікти у досліджуваного, демонструють, як дитина сприймає взаємостосунки з іншими членами сім'ї та своє місце в ній.

Використовуючи тест КМС, слід мати на увазі, що кожен малюнок $€$ творчою діяльністю, яка не лише відображає сприйняття дитиною своєї сім’і, але й дозволяє дитині аналізувати, переосмислювати сімейні стосунки. У цьому розумінні малюнок сім’ї не лише відображає сучасне й минуле, але також спрямований і на майбутнє, оскільки при малюванні дитина інтерпретує ситуацію, вирішує проблему актуальних сімейних стосунків. У цей момент психолог може допомогти дитині зрозуміти свою ситуацію в родині, разом 3 ним відшукати можливості кращої адаптації 
дитини у своїй сім’ї. Проте слід уникати сугестивної, внесеної ззовні інтерпретації ситуації, надаючи можливість дитині самій зрозуміти й сприйняти стільки, скільки вона може, виходячи з їі психологічної зрілості.

Тест КМС складається 3 двох частин: малювання своєї сім'ї та бесіди після малювання. Для виконання тесту дитині пропонується папір формату A4, простий олівець (2M) і гумка. Інструкція досліджуваному: «Будь ласка, намалюй свою сім’ю так, щоб іï члени були чим-небудь зайняті». На всі уточнюючі запитання слід відповідати без яких-небудь вказівок. Ця інструкція дещо відрізняється від тієї, що використовується зазвичай: «Намалюй свою сім’ю так, щоб кожен пї член і ти були чимось зайняті». Інструкція дещо змінена, тому що вимога малювати всіх членів сім'ї та себе не дає можливості отримати цінну інформацію про

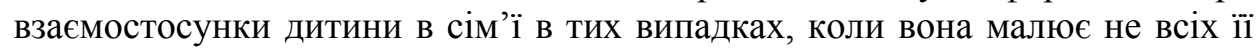
членів.

Під час малювання слід записувати всі спонтанні висловлювання дитини, відмічати ऑiі міміку, жести, а також фіксувати послідовність малювання. Після завершення малюнка 3 дитиною проводиться бесіда за наступною схемою: 1) хто намальований на малюнку, що робить кожен

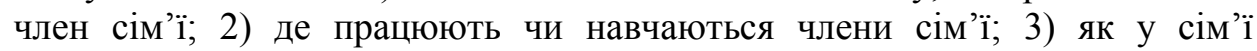
розподіляються домашні обов'язки; 4) які взаємостосунки дитини з іншими членами сім $\dddot{1}$.

Даний аналіз «Кінетичного малюнка сім'ї» спирається на систему інтерпретації, розроблену Р. Бернсом та С. Кауфманом [Burns \& Kaufman, 1970], використовує каталог інтерпретації С. Р. Рейнолдса [Reynolds, 1978], а також систему інтерпретації, запропоновану Г. Хоментаусткасом [Chomentauskas, 1983].

У системі кількісної оцінки КМС враховуються формальні та змістові аспекти малюнка. Формальними особливостями малюнка вважаються якість ліній малюнка досліджуваного, розміщення об'єктів малюнка на папері, витирання малюнка чи його окремих частин, заштриховування окремих частин малюнка. Змістовими характеристиками малюнка є зображена діяльність членів сім’і, представлених на малюнку, їхня взаємодія та розміщення, а також співвідношення речей і людей на малюнку.

При інтерпретації КМС головна увага звертається на наступні аспекти: 1) аналіз структури малюнка сім’ї (порівнювання складу реальної та намальованої сім’ї, розміщення та взаємодія членів сім’ї на малюнку); 2) аналіз особливостей намальованих окремих членів сім’ї (відмінності у стилі малювання, кількість деталей, схема тіл окремих членів сім’ї); 3) аналіз процесу малювання (послідовність малюнка, коментарі, паузи, емоційні реакції під час виконання завдання).

Розглянемо докладніше кожен аспект схеми інтерпретації. 


\section{Psychology}

1. Дитина не завжди малює всіх членів сім'ї. Зазвичай вона не малює тих, з ким перебуває в конфліктних стосунках. Іноді діти малюють людей, які реально не входять до складу сім’ї.

Розміщення членів сім’ї на малюнку часто показує їхні взаємостосунки. Наприклад, важливим показником психологічної близькості $€$ реальна відстань між окремими членами сім’ї. Іноді між окремими членами сім'ї малюють різні об'єкти, які створюють перешкоду між ними. Так, доволі часто можна побачити малюнок, на якому батько сидить, заховавшись за газетою, чи біля телевізора, який відділяє його від сім’і. Мати часто зображується біля плити, яка забирає всю іiі увагу. Спільна діяльність членів сім'ї свідчить про сприятливі сімейні стосунки. Малюючи свою сім’ю, деякі діти зображують усі фігури дуже маленькими та розміщують їх на нижній частині аркуша. Це може свідчити про депресивність дитини, про їі почуття неповноцінності в сімейній ситуації. На деяких малюнках домінують не люди, а речі, найчастіше меблі. Припускають, що це також відбиває емоційне занепокоєння дитини 3 приводу сімейної ситуації, і вона відкладає малювання членів сім’ї, а малює речі, які не мають емоційної значущості.

2. Уважається, що дитина найбільш деталізує, довше малює та прикрашає фігуру її найулюбленішого члена сім’і. I навпаки, якщо дитина негативно ставиться до кого-небудь, то малює цю людину неповно, без деталей, іноді навіть без основних частин тіла. Коли стосунки дитини конфліктні та тривожні, емоційно неоднорідно забарвлені, вона часто

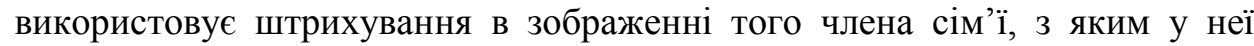
склалися афективні зв'язки. В аналогічних випадках спостерігається витирання та перемальовування. Важливе діагностичне значення має неадекватний розмір фігури. Наприклад, дитина намалювала молодшу сестру не тільки більшою від себе, але й більшою від батьків. Це свідчить про ту виключну увагу, яку батьки надають молодшій сестрі, про ii особливе місце в ієрархії сімейних сосунків.

Необхідно відмітити, що в малюнках, особливо дітей молодшого шкільного віку, спостерігається декілька стилів малювання. Часто одним стилем малюють батька та брата, іншим - матір та сестру. Особливо відрізняється тип промальовування волосся, одягу. За тим, як дитина малює себе, можна зрозуміти, 3 ким вона сильніше ідентифікується (з матір'ю чи батьком), чи адекватно це статі дитини.

3. Аналіз процесу малювання дає багату інформацію не лише про сімейні стосунки дитини, але й взагалі про стиль ії роботи. Коли діти, особливо середнього та старшого шкільного віку, відмовляються виконувати завдання, аргументуючи тим, що вони не вміють малювати, це цілком нормально і зрозуміло. Психолог може заспокоїти дитину, сказати, що тут важливо не стільки красиво намалювати, скільки придумати діяльність для членів сім'ї. Але бувають діти, численні відмови яких, а також манера прикривання намальованого рукою можуть свідчити про 
невпевненість дитини у власних силах, про ії потребу в підтримці з боку дорослого. Найчастіше свій малюнок дитина починає із зображення того члена сім'ї, до якого вона дійсно добре ставиться. Іноді спостерігаються паузи перед тим, як дитина починає малювати одну з фігур. Це в деяких випадках може свідчити про емоційно неоднозначне або навіть негативне ставлення дитини. У коментарях також може проступати ії ставлення до членів сім'ї, але під час виконання тесту психологу не слід вступати в розмову з дитиною.

Для тесту КМС також була розроблена система кількісної оцінки (табл. 1). Виділено п'ять симптомокомплексів: 1) сприятлива сімейна ситуація; 2) тривожність; 3) конфліктність у сім’ї; 4) почуття неповноцінності; 5) ворожість у сімейній ситуації.

Таблиця 1

Симптомокомплекси «Кінетичного малюнка сім'ї»

\begin{tabular}{|c|c|c|c|}
\hline $\begin{array}{l}\text { Симптомо- } \\
\text { комплекс }\end{array}$ & № & Симптом & Бали \\
\hline \multirow{9}{*}{$\begin{array}{l}\text { Сприятлива } \\
\text { сімейна } \\
\text { ситуація }\end{array}$} & 1 & Спільна діяльність усіх членів сім’ї & 0,2 \\
\hline & 2 & Переважання людей на малюнку & 0,1 \\
\hline & 3 & Зображення всіх членів сім’ї & 0,2 \\
\hline & 4 & Відсутність ізольованих членів сім’ї & 0,2 \\
\hline & 5 & Відсутність заштриховування & 0,1 \\
\hline & 6 & Гарна якість ліній & 0,1 \\
\hline & 7 & Відсутність показників ворожості & 0,2 \\
\hline & 8 & Адекватний розподіл людей на аркуші & 0,1 \\
\hline & 9 & Інші можливі ознаки & \\
\hline \multirow{10}{*}{ Тривож-ність } & 1 & Штрихування & $0,1,2,3$ \\
\hline & 2 & Лінія основи - підлога & 0,1 \\
\hline & 3 & Лінія над малюнком & 0,1 \\
\hline & 4 & Лінія із сильним натиском & 0,1 \\
\hline & 5 & Витирання & $0,1,2$ \\
\hline & 6 & Перебільшена увага до деталей & 0,1 \\
\hline & 7 & Переважання речей & 0,1 \\
\hline & 8 & Подвійні або перервані лінії & 0,1 \\
\hline & 9 & Підкреслення окремих деталей & 0,1 \\
\hline & 10 & Інші можливі ознаки & \\
\hline \multirow{8}{*}{$\begin{array}{l}\text { Конфлікт- } \\
\text { ність у сім’ї }\end{array}$} & 1 & Бар'єри між фігурами & 0,2 \\
\hline & 2 & Витирання окремих фігур & $0,1,2$ \\
\hline & 3 & $\begin{array}{l}\text { Відсутність основних частин тіла у деяких } \\
\text { фігур }\end{array}$ & 0,2 \\
\hline & 4 & Виділення окремих фігур & 0,2 \\
\hline & 5 & Ізоляція окремих фігур & 0,2 \\
\hline & 6 & Неадекватний розмір окремих фігур & 0,2 \\
\hline & 7 & $\begin{array}{llll}\text { Невідповідність } \\
\text { малюнка }\end{array}$ & 0,1 \\
\hline & 8 & Переважання речей на малюнку & 0,1 \\
\hline
\end{tabular}


Psychology

\begin{tabular}{|c|c|c|c|}
\hline & 9 & Відсутність на малюнку деяких членів сім’ї & 0,2 \\
\hline & 10 & Член сім’ї, який стоїть спиною & 0,1 \\
\hline & 11 & Інші можливі ознаки & \\
\hline \multirow{9}{*}{$\begin{array}{l}\text { Почуття } \\
\text { неповноцінн } \\
\text { ості }\end{array}$} & 1 & Автор малюнка непропорційно маленький & 0,2 \\
\hline & 2 & Розміщення фігур у нижній частині аркуша & 0,2 \\
\hline & 3 & Лінія слабка, переривчаста & 0,1 \\
\hline & 4 & Ізоляція автора від інших & 0,2 \\
\hline & 5 & Маленькі фігури & 0,1 \\
\hline & 6 & Нерухома в порівнянні з іншими фігура автора & 0,1 \\
\hline & 7 & Відсутність автора & 0,2 \\
\hline & 8 & Автор стоїть спиною & 0,1 \\
\hline & 9 & Інші можливі ознаки & \\
\hline \multirow{8}{*}{$\begin{array}{l}\text { Ворожість } \quad \text { у } \\
\text { сімейній } \\
\text { ситуації }\end{array}$} & 1 & $\begin{array}{l}\text { Одна з фігур на іншому аркуші або на звороті } \\
\text { аркуша }\end{array}$ & 0,2 \\
\hline & 2 & Агресивна позиція фігури & 0,1 \\
\hline & 3 & Закреслена фігура & 0,2 \\
\hline & 4 & Деформована фігура & 0,2 \\
\hline & 5 & Зворотний профіль & 0,1 \\
\hline & 6 & Руки розкинуті в боки & 0,1 \\
\hline & 7 & Пальці довгі, підкреслені & 0,1 \\
\hline & 8 & Інші можливі ознаки & \\
\hline
\end{tabular}

А. Баркан [Баркан, 2014] пропонує спосіб інтерпретації результатів тесту «Малюнок сім'ї», який дозволяє виявити особливості сімейної взаємодії та сімейних стосунків, роль дитини в сім'ї та стилі батьківського виховання.

Для виявлення особливостей сімейної взаємодії та сімейних стосунків автор пропонує такі параметри інтерпретації малюнка: послідовність виконання завдання; сюжет малюнка; послідовність розміщення членів сім'ї; розміри фігур членів сім’ї; величина простору між зображенням окремих членів сім'ї; місце розміщення дитини на малюнку; зображення дитиною сім'ї без себе; зображення дитиною сім'ї без якогось iї члена; «доповнення» своєї сім'ї неіснуючими родичами або сторонніми людьми; зображення дитиною замість сім'ї тільки самого себе; особливості вимальовування обличчя та інших частин тіла; гамма кольорів малюнка.

Для визначення ролі дитини в сім'ї та стосунків між іншими іiі членами аналізуються такі параметри інтерпретації малюнка: емоційна прив'язаність дитини до одного з батьків; нехтування дитиною в сім'ї (емоційне неприйняття); конфліктна ситуація в сім'ї; неприйняття одного 3 батьків; ревнощі до братів і сестер; неповна сім'я; єдина дитина.

Методика дозволяє розпізнати різні типи виховання дітей за малюнками: «кумир» сім’ї; гіперопіка; гіпоопіка; занедбаність (бездоглядність); виховання за типом «Попелюшки»; «цупкі шори»; виховання за типом підвищеної моральної відповідальності; виховання «в 
культі хвороби»; виховання за типом «кронпринца»; суперечливе виховання.

У практиці психологічної діагностики та корекції використовуються модифікації тесту «Малюнок сім’ї»:

1. Завдання намалювати сім’ю, яка зайнята якоюсь справою, наприклад, «сім'я, яка збирає урожай яблук».

2. Завдання намалювати сім'ю, яка потрапила в якусь скрутну ситуацію, наприклад, «сім'я під дощем».

3. Використання кольорових олівців. гномиків...).

4. Сім'я у вигляді символів (сім'я тварин, неіснуючих тварин,

5. Використання тесту для дорослих і всієї сім’ї загалом, коли кожен член сім’ї малює своє «бачення» на окремому аркуші паперу.

6. Сумісний малюнок сім'ї, який виконують одночасно на одному аркуші паперу всі члени сім'ї. Діагностичне значення в цьому випадку мають також способи взаємодії, які використовуються сім'єю в ситуації спільного завдання.

Висновки. Графічні методи - це робота 3 невербальним матеріалом, що дозволяє суттєво розширити як віковий діапазон, так і можливості міжкультурного використання. Результати малюнкових проб, маючи проективний характер, менше піддаються контролю свідомості та, відповідно, їхня інформативність має особливу цінність. Відмічено, що в малюнках корисної для психолога інформації більше, ніж навіть у рукописних текстах. Результати виконання таких тестів адресовані не до логічних форм мислення, а безпосередньо до образного його змісту, і смисл графічного зображення виявляється психологічно досить складним. Тому тут в єдиній «злитій» формі представлено і образ, і ставлення людини до світу, і особистий досвід переживання суб'єкта. Описана схема аналізу результатів графічних методик знижує ступінь суб'єктивності в їхній інтерпретації. Будучи доповненою інформацією, отриманою в ході бесіди 3 досліджуваним, вона дозволяє навіть психодіагносту-початківцю давати досить достовірні заключення щодо особистісних особливостей досліджуваного.

\section{ЛITEPАТУРА}

Баркан, 2014 - Баркан А. И. О чем говорят рисунки детей: руководство для родителей и педагогов. Москва : Этерна, 2014. 207 с.

Беляускайте, 1987 - Беляускайте Р. Ф. Рисуночные пробы как средство диагностики развития личности ребенка. Диагностическая и коррекиионная работа школьного психолога : сб. науч. тр. / редкол. : И. В. Дубровина (отв. ред.) и др. Москва : Изд-во АПН СССР, 1987. C. $67-80$.

Бернс, Кауфман, 2000 - Бернс Р. С., Кауфман С. Х. Кинетический рисунок семьи. Москва : Смысл, 2000. 146 с.

Бурлачук, 2007 - Бурлачук Л. Ф. Словарь-справочник по психодагностике. 3-е изд. СанктПетербург : Питер, 2007. 688 с. 


\section{Psychology}

Дилео, 2001 - Дилео Д. Детский рисунок. Диагностика и интерпретация. Москва : Апрель-Пресс, Изд-во ЭКСМО-пресс, 2001. $272 \mathrm{c.}$

Семаго, Семаго, 2005 - Семаго Н. Я., Семаго М. М. Теория и практика оценки психического развития ребенка. Дошкольный и младший школьный возраст. СПб. : Речь, 2005. 384 с.

Хоментаускас, 1985 - Хоментаускас Г. Т. Отражение межличностных отношений в диагностических рисунках семьи : автореф. дисс. на соиск. учен. ст. канд. психол. наук : 19.00.01. Москва, 1985. 21 с.

Хоментаускас, 2004 - Хоментаускас Г. Т. Психодиагностика межличностных отношений. Методика «Рисунок семьи». Общая психодиагностика / под ред. А. А. Бодалева, В. В. Столина. Санкт-Петербург : Изд-во «Речь», 2004. С. 292-313.

Burns \& Kaufman, 1970 - Burns R. \& Kaufman S. Kinetic family drawing (K-F-D): an introduction to understanding children through kinetic drawings. New York: Brunner/Mazel, 1970. $160 \mathrm{p}$.

Burns \& Kaufman, 2013 - Burns R. \& Kaufman S. Actions, styles and symbols in kinetic family drawing (K-F-D): an interpretive manual. New York: Brunner/Mazel, 2013. 304 p.

Chomentauskas, 1983 - Chomentauskas G. Šeimos piešimo metodikos Taikymas vaiko psichologiniams tyrimams. Metodinè priemonè. Vilnius: Pedagogikos mokslinio tyrimo institutas. 1983.

Corman, 1964 - Corman L. The family drawing test in medical-pedagogical practice. P.U.F, Paris, 1964.

DiLeo, 1973 - DiLeo J. H. Children`s drawings as diagnostic aids. New York : Brunner/Mazel, 1973.

Hulse, 1951 - Hulse W. C. The emotionally disturbed child draws his family. Quarterly of child behavior. 1951. Vol. 3. Pp. 152-174.

Hulse, 1952 - Hulse W. Childhood conflict expressed through family drawings. Journal of projective techniques. 1952. Vol. 16(1). Pp. 66-79.

Kaduson, 2003 - Kaduson H. G. Make a family drawing. In H. G. Kaduson \& C. E. Schaefer (Eds.). 101 favorite play therapy techniques. 2003. Vol. 3. Pp. 93-95. Norhtvale, NJ: Jason Aronson.

Reynolds, 1978 - Reynolds C. R. A quick-scoring guide to the interpretation of children's Kinetic Family Drawings (KFD). Psychology in the Schools. 1978. Vol. 15. Pp. 489-492.

Shearn, Russell, 1969 - Shearn C. and Russell K. Use of the family drawing as a technique for studying parent-child interaction. Journal of projective techniques. 1969. Vol. 33. Pp. 35-44.

\section{REFERENCES}

Barkan, 2014 - Barkan A. I. O chem govoriat risunki detei: rukovodstvo dlia roditelei i pedagogov. Moskva : Eterna, 2014. $207 \mathrm{~s}$.

Beliauskaite, 1987 - Beliauskaite R. F. Risunochnye proby kak sredstvo diagnostiki razvitiia lichnosti rebenka. Diagnosticheskaia i korrektsionnaia rabota shkolnogo psikhologa: sb. nauch. tr. I redkol. : I. V. Dubrovina (otv. red.) i dr. Moskva : Izd-vo APN SSSR, 1987. S. 67-80.

Berns, Kaufman, 2000 - Berns R. S., Kaufman S. Kh. Kineticheskii risunok semi. Moskva : Smysl, 2000. $146 \mathrm{~s}$.

Burlachuk, 2007 - Burlachuk L. F. Slovar-spravochnik po psikhodagnostike. 3-e izd. Sankt-Peterburg : Piter, 2007. $688 \mathrm{~s}$.

Dileo, 2001 - Dileo D. Detskii risunok. Diagnostika i interpretatsiia. Moskva : Aprel-Press, Izd-vo EKSMO-press, 2001. $272 \mathrm{~s}$.

Semago, Semago, 2005 - Semago N. Ia., Semago M. M. Teoriia i praktika otsenki psikhicheskogo razvitiia rebenka. Doshkolnyi i mladshii shkolnyi vozrast. Sankt-Peterburg : Rech, 2005. $384 \mathrm{~s}$.

Khomentauskas, 1985 - Khomentauskas G. T. Otrazhenie mezhlichnostnykh otnoshenii v diagnosticheskikh risunkakh semi : avtoref. diss. na soisk. uchen. st. kand. psikhol. nauk : 19.00.01. Moskva, 1985. $21 \mathrm{~s}$.

Khomentauskas, 2004 - Khomentauskas G. T. Psikhodiagnostika mezhlichnostnykh otnoshenii. Metodika «Risunok semi». Obshchaia psikhodiagnostika / pod red. A. A. Bodaleva, V. V. Stolina. Sankt-Peterburg : Izd-vo «Rech», 2004. S. 292-313. 